\title{
Understanding the management logic of private forest owners: A new approach
}

\author{
Ana Novais, Maria João Canadas* \\ Instituto Superior de Agronomia/Universidade Técnica de Lisboa, Tapada da Ajuda, 1349-017 Lisboa, Portugal
}

\section{A R T I C L E I N F O}

\section{Article history:}

Received 28 July 2008

Received in revised form 1 September 2009

Accepted 9 September 2009

\section{Keywords:}

NIPF owners

Forest management practices

Forest work

Outsourcing

Family work

Forest technology

\begin{abstract}
A B S T R A C T
Recently, several typologies of non-industrial private forest owners were established in order to assess their objectives and attitudes toward forests. However, current management practices and work organization have usually not been explicitly addressed in these empirically based typologies. In a context of increasing outsourcing and decreasing family work in forests, it is important to know the forest practices, who carries them out, and with whose labour and equipment. The interrelated knowledge of these variables sheds light on the constraints faced by different forest owners and about the agents caring for their forests. Such knowledge can also improve the understanding of forest owners' behaviour and, therefore, be useful for the design and implementation of forest policies. The work models of Portuguese non-industrial private forest were identified with these goals in mind. A cluster analysis, using a representative nationwide sample and an empirically based set of variables, was instrumental in identifying six work models. The interrelation amongst these models and other variables such as landholding attributes (e.g. forest size and dominant species), owners' social profile, and their economic goals was also assessed. Finally, the main dynamics of private owners' forest management are outlined.
\end{abstract}

(C) 2009 Elsevier B.V. All rights reserved.

\section{Introduction}

Non-industrial private forests, that is, forestlands privately owned by farmers, individuals, or corporations other than forest industries, account for much of the total forest area of several European countries (Harrison et al., 2002; Brandl, 2007). Non-industrial private forests (NIPF) represented 73\% of the total Portuguese forest area in 1995 (Radich and Baptista, 2005).

Following the recognition of the importance of non-industrial ownership for the successful implementation of a forest policy, in recent years several NIPF owner typologies have been built to assess the diversity and social context of forest management (Karpinnen, 1998; Masden, 2003, Dhubháin et al., 2006; Emtage et al., 2007; Marey et al., 2007). Nevertheless, very few forest owners' typologies have focused on the characterization of management practices and work organization (Boon and Meilby, 2007). In a review of these typologies, Dhubháin et al. (2006) consider them to centre on the values and objectives of forest owners, rarely addressing the explicit link between those objectives and actual management practices. Not surprisingly, forestry work organization is normally absent from these empirically based typologies.

However, in more qualitative approaches, it has frequently been assumed that work organization is a differentiating factor between

\footnotetext{
* Corresponding author. Departamento de Economia Agrária, Instituto Superior de Agronomia, Tapada da Ajuda, 1349-017 Lisboa, Portugal. Tel.: +351 213653332; fax: +351213620743.

E-mail addresses: ananovais@isa.utl.pt (A. Novais), mjcanadas@isa.utl.pt (M.J. Canadas).
}

industrial and non-industrial forest owners, large-scale and small-scale properties, farmers and non-farmers, or rural and urban residents. The difference between farming and non-farming or urban and rural residence is said to be related to different family work availability, attitudes toward work, and possibilities of transferring skills and equipment from the farm to the forest (Normandin, 1996; Díaz and Fonseca, 2000; Kvarda, 2004; Ziegenspeck et al., 2004; Herbohn, 2006). Verifying these matters requires knowledge of the relationship between management practices and the work organization patterns of private forest owners. This system of interrelationships is called "work model" (Canadas, 1998).

In fact, the socioeconomic analyses of forestry work and employment have been developed more in the context of industrial private owners and large public forestlands, and much less in the context of NIPF owners. From a general overview of those analyses, some features of work organization in forests, over the two last decades, can be emphasized: a trend toward an increase of outsourcing (Mäkinen, 1997; Janzen and Sanberg, 1998; Lilley et al., 2002); the expansion of outsourcing from transportation to timber felling and silvicultural operations (Poschen and Lovgren, 2001; Rummukainen et al., 2006); a decrease of family work, which in any event, remains more important in silvicultural practices than in harvesting operations (Nordfjell et al., 2005).

The increase in contracting out of forest work that was previously carried out in-house, is aimed at reducing fixed charges with equipment and permanent employment, and transferring financial risks and labour issues to forest contractors (Anderson et al., 1996; Janzen and Sanberg, 1998; Wang and Kooten, 1999; Clarke and Isaacs, 2005; Westermayer, 2006). Yet, this framework is insufficient for understanding work organization in NIPF forestlands, because this organization is not exclusively guided by entrepreneurial management logic (Schlüter, 
2007). Therefore, it is important to locate private owners in their social and economic contexts and to identify the criteria that direct their choices and decisions. That is, to find the explanation for the agents' economic behaviour (Novais, 2007).

For the French context, Normandin (1996) considered that most private forest owners managed their forests according to personal provisioning or savings considerations, and were not following the proper logic of a forest enterprise. For the whole of Portuguese private owners, Baptista and Santos (2005) distinguished between an entrepreneurial logic in forest management and forest viewed as a reserve fund. While in the first case, owners are motivated according to technical and profitability criteria, in the second, forest ownership is seen as a reserve of capital that can be called up when required.

Based on a survey of quantitative data, Baptista and Santos (2005) identified five NIPF owner types, clustered by the owners' motivations, forest income, accountability, forest follow up, investment, management practices, and forest area. The main goal of establishing this typology was to assess Portuguese private forest owners' economic rationality. Only one type (Forest Entreprise) is associated with entrepreneurial logic while, for the other four types, forest is seen as a reserve. They were termed as Investment-Reserve, Property-Reserve, Labour-Reserve, and HoldingReserve according to the presence or absence of the "execution of at least a silvicultural practice" and "realization of at least an investment" (Table 1).

The goal of this paper is to identify and characterize the work models of Portuguese NIPF owners and establish the relationship between those models and the owners' management logic. We seek to understand how forest work, as a whole, is organized and relates to management pratices. Work models are based on a definition of operations that cuts across different species. For instance, cork stripping and timber felling are included in the same category, designated "harvesting". This allows for comparisons that are independent of species. Each work model is a combination of operations defined in this broad sense, also considering the identity of the person responsible for the attendance and execution, type of labour force and equipment, and ownership of the equipment used in each of the operations.

This approach will contribute to an increased understanding of the management behaviour and logic of NIPF landowners, by revealing the constraints faced by forest owners and agents who carry out forestry work.

The paper is organized as follows. Methodology and data are presented in the next section. The main work models for Portuguese private forest and the attributes of owners and holdings are briefly summarized in the third section. Thereafter, discussion and some concluding remarks are presented.

\section{Methodology and data}

We use the same database as did Baptista and Santos (2005) in their study of the economic rationality of private forest owners in

\section{Table 1}

Economic rationalities of forest owners' types established by Baptista and Santos (2005).

\begin{tabular}{ll}
\hline Forest enterprise & $\begin{array}{l}\text { Owners are guided by technical and profitability criteria in } \\
\text { deciding harvest timing; they invest in forest and execute } \\
\text { silvicultural practices. } \\
\text { Owners do not invest or execute silvicultural practices and } \\
\text { forest is viewed as a reserve, harvest timing is mainly decided } \\
\text { by criteria other than profitability. }\end{array}$ \\
Investment-reserve & $\begin{array}{l}\text { Owners invest and harvest but do not carry out silvicultural } \\
\text { practices. }\end{array}$ \\
Labour-reserve & $\begin{array}{l}\text { Owners execute silvicultural practices but do not invest in the } \\
\text { forest, which is seen as a reserve. } \\
\text { Owners invest and carry out silvicultural practices and tend } \\
\text { Holding-reserve }\end{array}$ \\
& $\begin{array}{l}\text { to view forests as a reserve where they can harvest mainly } \\
\text { without profitability criteria. }\end{array}$ \\
\hline
\end{tabular}

Portugal. Empirical evidence relied upon interviews with 2406 owners, in the Portuguese Mainland. The data were gathered during 1999 and 2000 in 26 civil parishes ('freguesias') carefully selected in order to encompass the diversity of Portuguese forest, concerning dominant forest cover, size of forest properties, and the relationship of rural populations to the forest.

Cluster analysis is used in the identification of work models (similarity measure: Gower's coefficient; hierarchical agglomerative Ward's method). The objects of classification are the NIPF landowners who carried out forestry activities in the period 1989-1999, and since taking over responsibility for the forest, at least one of the following operations (1988 owners): harvesting, bush cleaning, thinning, pruning, spraying, or establishment. In the case of forest establishment this period was enlarged to 1979-1999 (Novais and Canadas, 2007).

The key-variables used in cluster analysis include nine nominal variables and one quantitative discrete variable. Nominal variables are: the person responsible for the execution of each of three operations, harvesting, bush cleaning, and stand tending $(1 \times 3)$; the main workforce, the type of equipment, and the ownership of the equipment for harvesting and cleaning $(3 \times 2)$. Harvesting refers to timber felling, cork stripping, or chestnut collecting, depending on the forest's main species. Stand tending includes thinning and pruning. Alternative values assumed by each variable are specified in Tables 2 , 3 , and 4 . The discrete variable is the number of types of silvicultural practices, such as stand tending, bush cleaning, and spraying.

The variables used to describe and characterize the work models include the forest owner's personal profile, forest attributes, the five owner types established by Baptista and Santos (2005), and the work organization modes for bush cleaning, harvesting, and stand tending. For each operation, these modes were identified by cluster analysis (the same cluster methodology as that used for work models) applied to the nominal variables corresponding to that operation (Tables 2, 3, and 4). The information on these individual variables is conveyed and discussed through the work organization modes. We opted not to present the individual variables themselves as it would result in excessive redundancy in the analysis. In each work model and work organization mode, and the analysis of adjusted standardized residuals allowed the identification of the variables' values that have significant deviation from expected values (SPSS, $P<0.05$ ).

For validating the solutions of the cluster analyses-the work models and the work organization modes by operation-significance tests on external variables were used. These are 16 variables concerning the forest property's location, forest owner's economic rationality, and other attributes of the owner's social profile (Table 5).

\section{Results: identification of work models}

For the set of Portuguese NIPF owners, six work models were identified. Their main differentiation represents the combination of internalization (I), externalization (E) or non-execution (N) of two operations: bush cleaning and harvesting (Table 6). ${ }^{1}$ Accordingly, these work models are designated as NI, NE, IN, II, IE, and EE.

The internalization of a forest operation is designated when the person responsible for its attendance and execution is the forest owner or a family member. Otherwise, when this is another person, the forest owner is considered to be externalizing that operation. When internalizing an operation, the work organization modes defined reflect the interrelationship between type of labour force, mechanization level, and equipment ownership. When externalizing, depending on the entity responsible for the attendance and execution of the operation, a distinction between subcontracting and

\footnotetext{
${ }^{1}$ Non-execution of harvesting necessarily occurs for holm oak stands, because felling is forbidden by law and none of the products associated with productive forest are obtained.
} 
Table 2

Work organization mode in bush cleaning.

\begin{tabular}{|c|c|c|c|c|c|}
\hline \multirow[b]{2}{*}{$\begin{array}{l}\text { Percentage of the number of forest owners that performed bush } \\
\text { cleaning, since the beginning of their management and in the period } \\
\text { 1989-1999, according to }\end{array}$} & \multicolumn{4}{|c|}{ Work organization in bush cleaning } & \multirow[b]{2}{*}{ Total } \\
\hline & $\begin{array}{l}\text { 1. Non- } \\
\text { executing }\end{array}$ & $\begin{array}{l}\text { 2. Executing by hand or with his own } \\
\text { clearing saw, using mainly own work } \\
\text { or family work }\end{array}$ & $\begin{array}{l}\text { 3. Executing, using a tractor, } \\
\text { mainly owned, and significantly } \\
\text { using wage work }\end{array}$ & 4. Subcontracting & \\
\hline \multicolumn{6}{|l|}{ The person responsible for the execution of bush cleaning } \\
\hline The forest owner & $0-$ & $100+$ & $100+$ & $0-$ & 46 \\
\hline Externalized (contractor, cooperative or association) & $0-$ & $0-$ & $0-$ & $100+$ & 20 \\
\hline Non-response & $100+$ & $0-$ & $0-$ & $0-$ & 34 \\
\hline \multicolumn{6}{|l|}{ The main workforce in bush cleaning } \\
\hline Own work or family work & $0-$ & $84+$ & $60+$ & $0-$ & 37 \\
\hline Wage work & $0-$ & $10+$ & $36+$ & $0-$ & 7 \\
\hline Externalized & $0-$ & $0-$ & $0-$ & $100+$ & 20 \\
\hline Did not perform & $100+$ & $0-$ & $0-$ & $0-$ & 34 \\
\hline Non-response, but performed & $0-$ & $6+$ & 3 & $0-$ & 2 \\
\hline \multicolumn{6}{|l|}{ The ownership of the equipment for bush cleaning } \\
\hline Own or borrowed & $0-$ & $24+$ & $79+$ & $0-$ & 15 \\
\hline Rented & $0-$ & 2 & $12+$ & $0-$ & 2 \\
\hline Externalized & $0-$ & $0-$ & $0-$ & $100+$ & 20 \\
\hline Did not perform & $100+$ & $0-$ & $0-$ & $0-$ & 34 \\
\hline Non-response, but performed & $0-$ & $74+$ & $9-$ & $0-$ & 29 \\
\hline \multicolumn{6}{|l|}{ Type of equipment for bush cleaning } \\
\hline By hand or with a clearing saw & $0-$ & $88+$ & $0-$ & $0-$ & 34 \\
\hline Motor equipment & $0-$ & $0-$ & $100+$ & $0-$ & 7 \\
\hline Externalized & $0-$ & $0-$ & $0-$ & $100+$ & 20 \\
\hline Did not perform & $100+$ & $0-$ & $0-$ & $0-$ & 5 \\
\hline Non-response, but performed & $0-$ & $12+$ & $0-$ & $0-$ & 34 \\
\hline
\end{tabular}

Note: ' + ' and '-' represent significant deviations from expected values at $P<0.05$ level (SPSS).

outsourcing to the product's buyer has been considered (Gradey, 2003; Westermayer, 2006). In subcontracting, that entity is a machine contractor, an association, or other forest service provider. In outsourcing to the buyer, that entity is also the purchaser of timber, cork, or another forest product.

A characterization of the six work models is now outlined, according to the work organization modes previously defined for several operations, and according to other variables that also helped in the work models identification (Table 7). The properties and the owners' most important attributes complete that characterization (Table 8).

\subsection{Non-executing bush cleaning and internalizing harvesting (NI)}

Despite not doing bush cleaning, some of the forest owners included in this model (more than 25\%) carry out pruning and

Table 3

Work organization mode in harvesting.

\begin{tabular}{|c|c|c|c|c|c|c|}
\hline \multirow[b]{2}{*}{$\begin{array}{l}\text { Percentage of the number of forest owners that } \\
\text { performed harvesting, since the beginning of their } \\
\text { management and in the period 1989-1999, according to }\end{array}$} & \multicolumn{5}{|c|}{ Work organization in harvesting } & \multirow[b]{2}{*}{ Total } \\
\hline & $\begin{array}{l}\text { 1. Non- } \\
\text { executing }\end{array}$ & $\begin{array}{l}\text { 2. Executing, using his own } \\
\text { tractor or forest machine, } \\
\text { and own or family work }\end{array}$ & $\begin{array}{l}\text { 3. Executing, without } \\
\text { using a tractor and } \\
\text { mostly using family } \\
\text { work }\end{array}$ & $\begin{array}{l}\text { 4. Executing, using a } \\
\text { tractor, mainly rented, } \\
\text { and using wage work }\end{array}$ & $\begin{array}{l}\text { 5. Outsourcing } \\
\text { to the buyer }\end{array}$ & \\
\hline \multicolumn{7}{|l|}{ The person responsible for the execution harvesting } \\
\hline The forest owner or family member & $0-$ & $100+$ & $100+$ & $100+$ & $0-$ & 26 \\
\hline Externalized (buyer or contractor) ${ }^{\mathrm{a}}$ & $0-$ & $0-$ & $0-$ & $0-$ & $100+$ & 44 \\
\hline Non-response & $100+$ & $0-$ & $0-$ & $0-$ & $0-$ & 31 \\
\hline \multicolumn{7}{|l|}{ The main workforce in harvesting } \\
\hline Owner work, family work, or mutual aid & $0-$ & $93+$ & $51+$ & $0-$ & $0-$ & 7 \\
\hline Wage work & $0-$ & $7-$ & $30+$ & $100+$ & $0-$ & 17 \\
\hline Externalized & $100+$ & $0-$ & $0-$ & $0-$ & $100+$ & 44 \\
\hline Did not perform & $0-$ & $0-$ & $0-$ & $0-$ & $0-$ & 31 \\
\hline Non-response, but performed & $0-$ & 0 & $19+$ & $0-$ & $0-$ & 1 \\
\hline \multicolumn{7}{|l|}{ The ownership of the equipment for harvesting } \\
\hline Own or borrowed & $0-$ & $78+$ & $0-$ & $31+$ & $0-$ & 7 \\
\hline Rented & $0-$ & $18+$ & $0-$ & $69+$ & $0-$ & 10 \\
\hline Externalized & $100+$ & $0-$ & $0-$ & $0-$ & $100+$ & 43 \\
\hline Did not perform & $0-$ & $0-$ & $0-$ & $0-$ & $0-$ & 31 \\
\hline Non-response, but performs harvesting & $0-$ & 3 & $100+$ & $0-$ & $0-$ & 9 \\
\hline \multicolumn{7}{|l|}{ Type of equipment for harvesting } \\
\hline $\begin{array}{l}\text { By hand or with clearing saw without motorized } \\
\text { transportation }\end{array}$ & $0-$ & $11+$ & $25+$ & $0-$ & $0-$ & 2 \\
\hline $\begin{array}{l}\text { By hand or with clearing saw with motorized } \\
\text { transportation }\end{array}$ & $0-$ & $62+$ & $3-$ & $100+$ & $0-$ & 16 \\
\hline Clearing saw and mechanical loading & $0-$ & $22+$ & $0-$ & 0 & $0-$ & 1 \\
\hline Externalized & $100+$ & $0-$ & $0-$ & $0-$ & $100+$ & 44 \\
\hline Did not perform & $0-$ & $0-$ & $0-$ & $0-$ & $0-$ & 31 \\
\hline Non-response, but performs harvesting & $0-$ & 5 & $72+$ & $0-$ & $0-$ & 6 \\
\hline
\end{tabular}

Note: '+' and '-' represent significant deviations from expected values at $P<0.05$ level (SPSS).

a Outsourcing to the buyer represents $97 \%$ of the owners that externalize harvesting. 
Table 4

Work organization mode in stand tending.

\begin{tabular}{|c|c|c|c|c|c|}
\hline \multirow[b]{2}{*}{$\begin{array}{l}\text { Percentage of the number of forest owners that performed stand tending, since the } \\
\text { beginning of their management and in the period 1989-1999, according to }\end{array}$} & \multicolumn{4}{|c|}{ Work organization in stand tending } & \multirow[b]{2}{*}{ Total } \\
\hline & $\begin{array}{l}\text { 1. Non- } \\
\text { executing }\end{array}$ & $\begin{array}{l}\text { 2. Executing, using his own } \\
\text { equipment, and own or family } \\
\text { work }\end{array}$ & $\begin{array}{l}\text { 3. Executing } \\
\text { with wage } \\
\text { work }\end{array}$ & 4. Subcontracting & \\
\hline \multicolumn{6}{|l|}{ The person responsible for the execution of stand tending } \\
\hline The forest owner or family member & $0-$ & $100+$ & $100+$ & $100+$ & 19 \\
\hline Externalized & $0-$ & $0-$ & $0-$ & $0-$ & 5 \\
\hline Non-response & $100+$ & $0-$ & $0-$ & $0-$ & 76 \\
\hline \multicolumn{6}{|l|}{ The main workforce in stand tending } \\
\hline Owner work or family work & & $82+$ & 9 & $0-$ & 11 \\
\hline Wage work & $0-$ & $0-$ & $91+$ & $0-$ & 6 \\
\hline Externalized & $0-$ & $0-$ & $0-$ & $100+$ & 5 \\
\hline Did not perform & $100+$ & $0-$ & $0-$ & $0-$ & 76 \\
\hline Non-response, but performed & $0-$ & $18+$ & 0 & 0 & 2 \\
\hline \multicolumn{6}{|l|}{ The ownership of the equipment for stand tending } \\
\hline Own or borrowed & $0-$ & $56+$ & $46+$ & $0-$ & 10 \\
\hline Rented & $0-$ & $0-$ & $43+$ & 0 & 3 \\
\hline Externalized & $0-$ & $0-$ & $0-$ & $100+$ & 5 \\
\hline Did not perform & $100+$ & $0-$ & $0-$ & $0-$ & 76 \\
\hline Non-response, but performed & $0-$ & $44+$ & $11+$ & $0-$ & 6 \\
\hline
\end{tabular}

Note: '+' and '-' represent significant deviations from expected values at $P<0.05$ level (SPSS).

thinning, with their own or their family members' labour. Still, this group of owners shows one of the lowest average numbers (0.5) of types of silvicultural practices. Most of these owners engage directly in harvesting, following organization modes, in which mainly the owner's or his family's work is applied (44\%) or, less often, wage work is mobilized (20\%). They stand out in forest establishment, an operation running under their responsibility, with self or family labour force, for planting, and rented or own equipment, in soil preparation. The majority of them (67\%) own small and very small properties and, for more than a third of the owners oak, holm oak, and chestnut (21\%) are the dominant species. Strongly associated with this model, these species are also the least represented in the sample. These owners also show a higher presence of women (38\%), greater importance of wages, especially agricultural wages (13\%), as the main source of income outside forest, and residence vicinity to forest property $(80 \%)$, in spite of being the least numerous in the daily attendance of the forest (65\%). Viewing forest as a reserve (87\%), its management is guided by a Property-Reserve (38\%) or InvestmentReserve logic (24\%), where there is an absence of investment in the first and its presence in the latter.

\subsection{Non-executing bush cleaning and externalizing harvesting (NE)}

Because these owners do not perform cleaning and stand tending, the average number of types of silvicultural practices they exhibit is practically zero. Harvesting is outsourced to the product's buyer charged with mobilizing the required workforce and equipment. In the universe of private owners, these stand out in forest establishment, in particular running under an outsider (responsibility) or resulting from wild germination and seedlings. They correspond to the group of owners who least apply their own or their family's labour. They are the oldest, with a comparatively higher rate of women's ownership (30\%), and lower proportion of owners living in the same civil parish where the forest is located (73\%), and having a

Table 5

Pearce chi-square test on external variables.

\begin{tabular}{|c|c|c|c|c|c|c|c|c|}
\hline \multirow[t]{3}{*}{ External Variables } & \multirow{2}{*}{\multicolumn{2}{|c|}{ Work models }} & \multicolumn{6}{|c|}{ Work organization mode in } \\
\hline & & & \multicolumn{2}{|c|}{ Bush cleaning } & \multicolumn{2}{|c|}{ Harvesting } & \multicolumn{2}{|c|}{ Stand tending } \\
\hline & $d f$ & Value $\chi^{2}$ & $d f$ & Value $\chi^{2}$ & $d f$ & Value $\chi^{2}$ & $d f$ & Value $\chi^{2}$ \\
\hline Region & 30 & $852 * * *$ & 24 & $1320 * * *$ & 18 & $784 * * * *$ & 18 & $550 * * *$ \\
\hline Forest property's main species & 25 & $1029 * * *$ & 20 & $2072 * * *$ & 15 & $668^{* * *}$ & 15 & $495^{* * *}$ \\
\hline Forest size & 20 & $363^{* * *}$ & 16 & $436 * * *$ & 12 & $476^{* * *}$ & 12 & $177^{* * *}$ \\
\hline Forest owner's gender & 5 & $68^{* * *}$ & 4 & $29 * * *$ & 3 & $61^{* * *}$ & 3 & 1 \\
\hline Forest owner's age group & 20 & $49 * * *$ & 16 & $57 * * *$ & 12 & $24^{*}$ & 12 & 18 \\
\hline Forest owner's education level & 20 & $67 * * *$ & 16 & $61 * * *$ & 12 & $107 * * *$ & 12 & $117 * * *$ \\
\hline Forest owner's residence & 10 & $40 * * *$ & 8 & $61 * * *$ & 6 & $73 * * *$ & 6 & $20^{* * *}$ \\
\hline Holding a farm (1. yes, 2. no) & 5 & $46^{* * *}$ & 4 & $41^{* * *}$ & 3 & $40 * * *$ & 3 & $15^{* *}$ \\
\hline Main source of owner's income besides forest & 25 & $74^{* * *}$ & 20 & $98^{* * *}$ & 15 & $45^{* * *}$ & 15 & $36^{* * *}$ \\
\hline Forest income regularity & 10 & $347^{* * *}$ & 8 & $610^{* * *}$ & 6 & $340 * * *$ & 6 & $145^{* * *}$ \\
\hline Weight of forestry income in the owner's income & 20 & $192^{* * *}$ & 16 & $290 * * *$ & 12 & $179 * * *$ & 12 & $60^{* * *}$ \\
\hline $\begin{array}{l}\text { Forest owners that daily follow their property, personally or through a } \\
\text { family member or a neighbour (1. yes, } 2 \text {. no) }\end{array}$ & 5 & $36^{* * *}$ & 4 & $26 * * *$ & 3 & $35^{* * *}$ & 3 & 5 \\
\hline Time gap after last visit to the forest & 15 & $110^{* * *}$ & & Not valid & 9 & $87^{* * *}$ & 9 & $37 * * *$ \\
\hline Harvest timing decision criterion & 8 & $117^{* * *}$ & 6 & $97^{* * *}$ & 6 & $44^{* * *}$ & 6 & $15^{*}$ \\
\hline Sale method & & & & & & & & \\
\hline $\operatorname{Timber}^{\mathrm{a}}$ (1. on the stump, 2 . other situation) & 5 & $271 * * *$ & 4 & $269 * * *$ & 3 & $35 * * *$ & 3 & 1 \\
\hline Timber $^{\mathrm{b}}$ (1. on the stump, 2 . other situation) & 5 & $262^{* * *}$ & 4 & $196^{* * *}$ & 3 & $77 * * *$ & 3 & $9 *$ \\
\hline Cork (1. at stack; 2 other situation) & 5 & $400 * * *$ & 4 & $876^{* * *}$ & 3 & $275^{* * *}$ & 3 & $25^{* * *}$ \\
\hline Economic rationalities of forest owner types (Baptista and Santos, 2005) & 20 & $1564^{* * *}$ & 16 & $427 * * *$ & 12 & $1542 * * *$ & 12 & $276^{* * *}$ \\
\hline
\end{tabular}

Note: ${ }^{* * *}$ significant at $0.001 ;{ }^{* *}$ significant at $0.01 ;{ }^{*}$ significant at 0.05 .

a Timber for cellulose.

b Saw and veneer logs. 
Table 6

Work models identification.

\begin{tabular}{lllll}
\hline \multirow{3}{*}{ Bush cleaning } & Harvesting & & \\
\cline { 3 - 5 } & & Non-executing & Internalizing & Externalizing \\
\hline & Non-executing & & NI & NE \\
& Internalizing & IN & II & IE \\
& Externalizing & & & EE \\
\hline
\end{tabular}

$\mathrm{NI}-$ Non-executing bush cleaning and internalizing harvesting. NE-Non-executing bush cleaning and externalizing harvesting. IN-Internalizing bush cleaning and non-executing harvesting. II-Internalizing bush cleaning and harvesting.

IE-Internalizing bush cleaning and externalizing harvesting.

EE-Externalizing bush cleaning and harvesting.

Blank cells correspond to non-existent combinations in the set of interviewed owners.

farm (64\%). Their properties are very small, small and medium sized and have pine (42\%), eucalyptus (36\%), and cork oak (20\%) as the main dominant species. This model is also characterized by the highest share of eucalyptus owners. Forest is viewed as a reserve where investment can be made, but no silvicultural operations are undertaken (Investment-Reserve, 25\%, and Property-Reserve, 54\%).

\subsection{Internalizing bush cleaning and non-executing harvesting (IN)}

The owners who incorporate this model carry out silvicultural practices using mainly their own or their family's labour and equipment, and a clearing saw when it comes to bush cleaning. They stand out for the highest number of types of silvicultural practices, about half of the owners performing three, four, or five types of practices. However, they do not harvest during the reference period and show the lowest rate of forest establishment. They own the smallest forest properties ( 10 ha average area), and have pine as the main dominant species (74\%). In fact, very small properties ( $<1 \mathrm{ha}$ ) and pine are characteristic features of this model. Socially, these owners are distinguished by a stronger presence of male gender (80\%), of wages from industry and services as chief source of income beyond forest (18\%), owners permanently living in the same civil parish where the forest is located (87\%), and daily attendance to it (83\%). The forest is seen as a small reserve intensively cared for, in order to ensure its productive capacity, applying labour (LabourReserve, 59\%) or simply performing silvicultural practices (HoldingReserve, 26\%).

\subsection{Internalizing bush cleaning and harvesting (II)}

These owners, who internalize forest operations, own the largest forest areas (63 ha on average) and employ the highest share of wage labour. In harvesting, using wage earners and a tractor, mainly rented, for the product's transportation, accounts for $59 \%$ of the owners. In bush cleaning, using wage labour and a tractor represents $45 \%$ of the owners, despite not numerically supplanting those using mainly family work and operating by hand or with their own clearing saw (55\%). Cork is the main source of forest income for these owners (cork oak being the dominant species for $64 \%$ of the properties), who show the highest rates of men owners (85\%) and farm holders (82\%). These owners are also characterized by having an entrepreneurial or

Table 7

Work models characterization: work organization and management practices.

\begin{tabular}{|c|c|c|c|c|c|c|c|}
\hline & \multicolumn{6}{|c|}{ Work models } & \multirow[t]{2}{*}{ Total } \\
\hline & $\mathrm{NI}$ & $\mathrm{NE}$ & IN & II & IE & $\mathrm{EE}$ & \\
\hline Number of forest owners queried & 320 & 353 & 402 & 157 & 357 & 399 & 1988 \\
\hline Percentage $(\%)$ & 16 & 18 & 20 & 8 & 18 & 20 & 100 \\
\hline \multicolumn{8}{|l|}{ Percentage of the number of forest owners according to } \\
\hline \multicolumn{8}{|l|}{ Work organization in bush cleaning } \\
\hline 1. Non-executing & $100+$ & $100+$ & $0-$ & $0-$ & $0-$ & $0-$ & 34 \\
\hline 2. Executing by hand or with his own clearing saw, using mainly own work or family work & $0-$ & $0-$ & $92+$ & $55+$ & $88+$ & $0-$ & 39 \\
\hline 3. Executing, using a tractor, mainly owned, and significantly using wage work & $0-$ & $0-$ & 8 & $45+$ & $12+$ & $0-$ & 7 \\
\hline 4. Subcontracting & $0-$ & $0-$ & $0-$ & $0-$ & $0-$ & $100+$ & 20 \\
\hline \multicolumn{8}{|l|}{ Work organization in harvesting } \\
\hline 1. Non-executing & $36+$ & $0-$ & $100+$ & $0-$ & $0-$ & $23-$ & 31 \\
\hline 2. Executing, using his own tractor or forest machine, and own or family work & $6+$ & $0-$ & $0-$ & $24+$ & $0-$ & $1-$ & 3 \\
\hline 3. Executing, without using a tractor and mostly using family work & $38+$ & $0-$ & $0-$ & $18+$ & $0-$ & $5-$ & 8 \\
\hline 4. Executing, using a tractor, mainly rented, and using wage work & $20+$ & $0-$ & $0-$ & $59+$ & $0-$ & $32+$ & 14 \\
\hline 5. Outsourcing to the buyer & $0-$ & $100+$ & $0-$ & $0-$ & $100+$ & $39-$ & 44 \\
\hline \multicolumn{8}{|l|}{ Work organization in stand tending } \\
\hline 1. Non-executing & $70-$ & $84+$ & 76 & 71 & 78 & 73 & 76 \\
\hline 2. Executing, using his own equipment, and own or family work & $18+$ & $7-$ & $15+$ & 10 & 13 & $9-$ & 12 \\
\hline 3. Executing, with wage work & 4 & $3-$ & 5 & $17+$ & $4-$ & $11+$ & 7 \\
\hline 4. Subcontracting & 8 & 6 & $4-$ & 2 & 5 & 7 & 5 \\
\hline \multicolumn{8}{|l|}{ The person responsible for establishment operations ${ }^{\mathrm{a}}$} \\
\hline The forest owner & $30+$ & 20 & $13-$ & 20 & 21 & $12-$ & 19 \\
\hline An outside entity & $9+$ & $10+$ & $1-$ & $1-$ & 5 & $13+$ & 7 \\
\hline Wild seedling & 3 & $9+$ & 3 & 1 & $6+$ & $2-$ & 4 \\
\hline \multicolumn{8}{|l|}{ Main work force in establishment when the forest owner is responsible for the operations ${ }^{\mathrm{a}}$} \\
\hline Own, family, or interchange work & $25+$ & 14 & $10-$ & 12 & $18+$ & $6-$ & 14 \\
\hline Wage labour & 3 & 3 & 2 & $6+$ & 2 & 5 & 3 \\
\hline \multicolumn{8}{|l|}{ Equipment ownership in establishment when the forest owner is responsible for the operations ${ }^{\mathrm{a}}$} \\
\hline Self-owned or borrowed & $10+$ & 4 & 4 & 6 & 6 & $2-$ & 5 \\
\hline Rented & $15+$ & 10 & 7 & 11 & $11-$ & $6-$ & 10 \\
\hline \multicolumn{8}{|l|}{ Number of types of silvicultural practices } \\
\hline 0 & $62+$ & $79+$ & $0-$ & $0-$ & $0-$ & $0-$ & 24 \\
\hline 1 & $24-$ & $18-$ & 49 & $62+$ & $59+$ & $62+$ & 45 \\
\hline 2 & $14-$ & $3-$ & $34+$ & $33+$ & $28+$ & $31+$ & 24 \\
\hline 3 & $0-$ & $0-$ & $14+$ & 5 & $12+$ & 6 & 6 \\
\hline 4 & 0 & $0-$ & $3+$ & 0 & 1 & 1 & 1 \\
\hline Average number of types of silvicultural practices & 0.5 & 0.0 & 1.7 & 1.4 & 1.6 & 1.5 & 1.2 \\
\hline
\end{tabular}

Note: '+' and '-' represent significant deviations from expected values at $P<0.05$ level (SPSS).

a The gap to $100 \%$ corresponds to the non-execution of establishment operations or non-answers. 
Table 8

Work models characterization: forest properties and forest owners.

\begin{tabular}{|c|c|c|c|c|c|c|c|}
\hline \multirow{2}{*}{$\begin{array}{l}\text { Number of forest owners queried } \\
(\%)\end{array}$} & \multicolumn{6}{|c|}{ Work models } & \multirow[t]{2}{*}{ Total } \\
\hline & NI & NE & IN & II & IE & $\mathrm{EE}$ & \\
\hline \multicolumn{8}{|l|}{ According to the forest size } \\
\hline$<1$ ha & 28 & 29 & $47+$ & $19-$ & 28 & $11-$ & 28 \\
\hline $1 \mathrm{a}<5$ ha & 39 & 37 & 40 & $24-$ & $44+$ & $26-$ & 36 \\
\hline $5 \mathrm{a}<20$ ha & 21 & 20 & $9-$ & 22 & 21 & $27+$ & 20 \\
\hline $20 \mathrm{a}<100$ ha & 10 & 9 & $2-$ & $23+$ & 5 & $27+$ & 12 \\
\hline$\geq 100$ ha & $2-$ & 5 & $2-$ & $12+$ & 3 & $10+$ & 5 \\
\hline \multicolumn{8}{|l|}{$\begin{array}{l}\text { According to the forest } \\
\text { property's main species }\end{array}$} \\
\hline Holm oak & $4+$ & $0-$ & $5+$ & $0-$ & $0-$ & $4+$ & 2 \\
\hline Oak & $10+$ & $2-$ & 4 & $12+$ & $1-$ & $1-$ & 4 \\
\hline Chestnut tree & $21+$ & $0-$ & $1-$ & 4 & $0-$ & $0-$ & 4 \\
\hline Eucalyptus & 22 & $36+$ & $15-$ & $13-$ & 23 & $17-$ & 22 \\
\hline Pine & $16-$ & 42 & $74+$ & $8-$ & $61+$ & $24-$ & 42 \\
\hline Cork oak & 27 & $20-$ & $1-$ & $64+$ & $15-$ & $55+$ & 27 \\
\hline That hold a farm ${ }^{1}$ & $60-$ & $64-$ & 72 & $82+$ & $77+$ & $75+$ & 71 \\
\hline That are men & $62-$ & $70-$ & $80+$ & $85+$ & $84+$ & $69-$ & 74 \\
\hline That are women & $38+$ & $30+$ & $20-$ & $15-$ & $16-$ & $31+$ & 26 \\
\hline \multicolumn{8}{|l|}{$\begin{array}{l}\text { According to the forest } \\
\text { owner's age group }\end{array}$} \\
\hline$<40$ years & 6 & 3 & 5 & 3 & $2-$ & 6 & 4 \\
\hline 40 a 49 years & 11 & 10 & 10 & 11 & 10 & 9 & 10 \\
\hline 50 a 59 years & 19 & 15 & 21 & 22 & $13-$ & 17 & 17 \\
\hline 60 a 69 years & $23-$ & $25-$ & 30 & 32 & $37+$ & 30 & 30 \\
\hline$\geq 70$ years & 41 & $47+$ & $34-$ & $32-$ & 38 & 38 & 39 \\
\hline \multicolumn{8}{|l|}{$\begin{array}{l}\text { According to the main source } \\
\text { of income besides forest }{ }^{2}\end{array}$} \\
\hline Agriculture and forestry wages & $13+$ & 6 & 5 & 9 & $10+$ & $4-$ & 8 \\
\hline Other wages & 16 & 16 & $18+$ & 10 & $10-$ & 16 & 15 \\
\hline Rural retirement pensions & 50 & 58 & 54 & 48 & $60+$ & 55 & 55 \\
\hline $\begin{array}{l}\text { Entrepreneurial or independent } \\
\text { activity in agriculture } \\
\text { or forestry }\end{array}$ & $6-$ & $6-$ & 6 & $20+$ & 10 & 10 & 8 \\
\hline $\begin{array}{l}\text { Other entrepreneurial or } \\
\text { independent activity }\end{array}$ & 7 & 7 & 6 & 5 & 4 & 6 & 6 \\
\hline Other source of income & 3 & 3 & 1 & 3 & $0-$ & $4+$ & 2 \\
\hline \multicolumn{8}{|l|}{$\begin{array}{l}\text { According to the forest } \\
\text { owner's residence }{ }^{2}\end{array}$} \\
\hline In the same freguesia & $80+$ & $73-$ & $87+$ & 72 & $85+$ & $65-$ & 78 \\
\hline In the same district & $9-$ & 16 & $10-$ & $20+$ & $10-$ & $22+$ & 14 \\
\hline Out of the district & 9 & 10 & 3 & 8 & 4 & $12+$ & 8 \\
\hline $\begin{array}{l}\text { That daily follow their property, } \\
\text { personally or through a family } \\
\text { member or a neighbour }{ }^{3}\end{array}$ & $65-$ & 74 & $83+$ & 81 & $85+$ & $70-$ & 76 \\
\hline \multicolumn{8}{|l|}{$\begin{array}{l}\text { According to economic rationality } \\
\text { (Baptista and Santos, 2005) }\end{array}$} \\
\hline Investment-Reserve & $24+$ & $25+$ & $0-$ & $0-$ & $0-$ & $0-$ & 8 \\
\hline Property-Reserve & $38+$ & $54+$ & 0 & $0-$ & $0-$ & $0-$ & 16 \\
\hline Labour-Reserve & $25-$ & $7-$ & $59+$ & 29 & $58+$ & 34 & 37 \\
\hline Holding-Reserve & $5-$ & $9-$ & $26+$ & 21 & $31+$ & 15 & 18 \\
\hline Forest enterprise & $8-$ & $5-$ & $15-$ & $50+$ & $11-$ & $51+$ & 21 \\
\hline Average forest size (ha) & 12 & 19 & 10 & 63 & 14 & 41 & 23 \\
\hline
\end{tabular}

Note: '+' and '-' represent significant deviations from expected values at $P<0.05$ level (SPSS).

The gap to $100 \%$ corresponds to: ${ }^{1}$ non-holders; ${ }^{2}$ anulled answers; ${ }^{3}$ other situations in which forest is followed by another responsible person, with or without technical education.

independent activity in agriculture and forestry and living in the same district where their estates are located. Their property is managed as a forest enterprise guided by technical and profitability criteria.

\subsection{Internalizing bush cleaning and externalizing harvesting (IE)}

The owners included in this model outsource harvesting to the buyer, the opposite of II. Regarding the weight of work organization modes based on self or family labour, and the number of types of silvicultural practices, these owners occupy a position between IN and II. According to this stronger family labour engagement, these owners are amongst those most distinguished by the proximity of the forest to their place of residence (85\%), the highest share of owners following their property daily (85\%), and the rate of men owners (84\%). The vast majority owns less than 20 ha of forest, covered chiefly with pine, eucalyptus, or cork oak, showing a strong association with small properties (44\%) and pine (61\%). Forest is viewed as a reserve, from which an irregular income can be derived, and in whose maintenance of productive capacity the owner, or the family, takes part with their labour.

\subsection{Externalizing bush cleaning and harvesting (EE)}

This model is most distinguished by the subcontracting of forest work to machine contractors and other service providers, especially with regard to bush cleaning. The owners outsourcing harvesting to the buyer's responsibility are numerically important (39\%). Yet, this model is characterized by the execution of this operation under the forest owner's responsibility, with wage labour and rented equipment (32\%). This work organization mode corresponds to the externalization of some of the tasks included in harvesting. Concerning the number of types of silvicultural practices, this work model comes close to the previous three models. Cork oak as the dominant species and cork as the leading source of forest income are characteristic of this model. Medium, large, and very large are the property sizes most associated with this model. It is notable for a stronger presence of women owners, and residents outside the district where property is located. In spite of their physical separation from the forest property and having relatively fewer owners following it daily, the majority of these owners guide their management by technical and profitability criteria, enforced by contracting out forest operations.

\section{Discussion and conclusions}

In the following discussion, one should keep in mind the complexity of the universe studied, as compared to other revised typologies of NIPF owners. Forest work has been taken as a whole, considering the full range of forest operations, in a representative nationwide sample of private forest owners, covering several forest species and products (timber, cork, and chestnut) with different technical procedures (felling, stripping, and collecting).

Applying the work model notion to the object of this study has proved useful for the identification of six types of NIPF owners showing a balanced sample distribution: $16 \%$ NI, $18 \%$ NE, $20 \%$ IN, $8 \%$ II, $18 \%$ IE, and $20 \% \mathrm{EE}$. In an articulated manner, the models inform us about the constraints on forest owners, the practices, and the agents performing them.

These work models differentiate mainly according to the way forest owners are internalizing, externalizing, or non-executing two operations: bush cleaning and harvesting. For the same forest owner, work organization modes are not necessarily similar in distinct operations: harvesting externalization combines with three different bush cleaning modes, and in its turn, bush cleaning internalization matches with three work organization modes for harvesting. From this typology it can be inferred that differentiation of work organization in forests can hardly be reduced to dual categories. For instance, family labour and wage labour or internalization and externalization (Wang and Kooten, 1999).

When analysing forestry management and work organization in the context of industrial private owners or large public forestlands, isolation of harvesting from other silvicultural practices is a normal procedure (Wang and Kooten, 1999; Vokoun et al., 2006). However, in the context of NIPF owners that same procedure implies gathering into the same category a range of forest owners that can be quite different concerning their behaviour as a whole. Along the same line, these work models differentiate according to forest size, dominant species, and farm holding. However, none of these variables is, on its own, enough for explaining the work models identified. 
Scale is amongst the most frequently considered factors in technical and economic analyses of forestry (Herbohn, 2006; Vokoun et al., 2006; Marey et al., 2007). II and EE are associated with larger properties, while the remaining models mainly comprise small properties. Amongst these latter models, those internalizing bush cleaning are even associated with very small and small properties, respectively, IN and IE.

The dominant species in the forest property necessarily affects management practices (Alves, 1982). II and EE are associated with cork oak, and IN with pine; IE and NE have a strong presence of pine and eucalyptus, IE being associated with pine and NE, eucalyptus.

Availability of family labour and allocation of farm equipment to forest activities have been considered as influential factors in NIPF owners' management (Kvarda, 2004; Ziegenspeck et al., 2004). While physical proximity of the forest to the owner's residence eases that availability, farm holding allows that allocation. Farm holding is characteristic of II, IE, and EE. Considering that externalization of all of the forest operations characterizes EE, only the other two models can give some support to the notion of equipment transfer from agriculture to forest work. In fact, the transfer of automotive machinery can more frequently occur in II. The use of a tractor, mainly owned by the forest owner, for mechanical bush cleaning or performing the products' primary transportation are amongst the more important work organization modes in this model.

Proximity of the owner's residence to the forest characterizes the work models NI, IN, and IE. These clusters show the greatest proportions of owners living near their forest, in the same civil parish. However, declared daily attendance to forests characterizes only the last two. Nevertheless, knowing that in these models internalization is undertaken mainly by family labour, we find support for the belief that proximity favours family engagement in forest work and, therefore, affects management.

Age, gender, and occupation are some of the forest owner attributes impacting his or her availability and skills for forestry work. It is not surprising that one of the most ageing groups of owners, with $47 \%$ being 70 or more years of age, is NE, the work model that has the smallest number of types of silvicultural practices, outsources harvesting, and is associated with eucalyptus.

Women owners are relatively more numerous in this last group of owners (NE), as well as in models NI and EE. All these owners choose non-execution or the subcontracting of bush cleaning. Conversely, the models characterized by bush cleaning internalization (IN, IE, and II) are associated with male owners. In the Portuguese forestry context, motor-manual and mechanical labour are mainly seen as male work. So, in-house bush cleaning, often done with a clearing saw, helps to explain the association between the internalization of that operation and male ownership.

Another pertinent result concerns the complementarity between the typology of work models here presented and the typology of economic rationalities established by Baptista and Santos (2005). This last typology gives insight into forest owners' management, explicitly addressing their objectives, and it can be expected that forest owners' objectives determine their management decisions (Dhubháin et al., 2006; Boon and Meilby, 2007). Indeed, entrepreneurial management logic and reserve logic differ regarding work models, with models II and EE associated with the former and the remaining models associated with the latter. According to Dhubháin et al. (2006), this is because owners following different objectives have different management behaviour. Note that the same economic logic of owners is compatible with different work models, as is the case with entrepreneurial logic (models II and EE). The same applies to the Labour-Reserve logic (models NE and NI). On the other hand, the same work model can be driven by different logics: for instance, IE (or IN) is associated with both the Labour and Holding-Reserve logics.

The findings suggest that both the analysis of forestry work and NIPF owners' behaviour can be improved by linking management practices to the social context of work organization-by revealing the relationships in which the person responsible, the work, and the equipment are employed for the set of forestry operations.

Concerning work model dynamics, some brief remarks can be made. In a context of decreasing family labour, relying mostly on an aged owner, those work models where internalization (especially of silvicultural practices) depend on family labour (IN and IE) are at risk. When forest is seen as a reserve fund, the non-execution of silvicultural practices is expected. Paying for others' work (with wage labour or contracting out) seems a less attractive alternative in forest operations, representing a long-run capital lockup and, in Portuguese forestry, a risky one. In order to counteract this negative trend, it is expected that social engineering trials in the realm of forest management, already present or forthcoming, can create new work models that address these forest owners' economic rationalities.

From a forest owners' perspective, this study of forest work also constitutes a framework for a future analysis of contractors' forest activity. As shown, externalization is important in various models, especially concerning harvesting (NE and IE), but also with regard to bush cleaning and stand establishment (EE). Knowing the circumstances and logic behind these agents' actions is crucial to understanding the technical and environmental content of their forest practices and designing the solutions and policies that will secure sustainable forest management.

\section{Acknowledgement}

The authors would like to thank Professor Fernando Oliveira Baptista from the DEASR of the Instituto Superior de Agronomia, for his insightful and constructive reviews of early drafts of the article, and for database access.

\section{References}

Alves, A., 1982. Técnicas de Produção Florestal. Instituto Nacional de Investigação Científica, Lisboa.

Anderson, C., Thompson, K.J., Psaltopoulos, D., 1996. Forestry contracting in northern Scotland: a survey report. Forestry 69 (2), 143-153.

Baptista, F., Santos, R., 2005. Os Proprietários Florestais: Resultados de um Inquérito. Celta, Oeiras.

Boon, T., Meilby, H., 2007. Describing management attitudes to guide forest policy implementation. Small-scale forestry 6, 79-90.

Brandl, H., 2007. The small-scale forestry group 1986-2006: an overview on the group activities during the last 20 years. Small-scale forestry $6,1-18$.

Canadas, M.J., 1998. Trabalho, Território e Tecnologia: Transformação e Situação Actual na Viticultura. Instituto Superior de Agronomia, Lisboa.

Clarke, J., Isaacs, M., 2005. Forestry Contractors in South Africa: What Role in Reducing Poverty? International Institute for Environment and Development, London.

Dhubháin, Á, Chobanova, R, Karppinen, H., Mizaraite, D., Ritter, E., Slee, B., Wall, S. 2006. The values and objectives of private forest owners and their influence on forestry behaviour: the implications for entrepreneurship. In: Niskanen, A. (Ed.), Issues Affecting Enterprise Development in the Forest Sector in Europe. University of Joensu, Faculty of Forestry, Joensu, pp.71-83.

Díaz, C., Fonseca, M., 2000. Cultura forestal e imágenes del monte: el aprovechamiento forestal en la pequeña agricultura familiar. Estudios Agrosociales y Pesqueros 189, 179-200.

Emtage, N., Herbohn, J., Harrison, S., 2007. Landholder profiling and typologies for natural resourse-management policy and program support: potential and constraints. Environmental Management 40, 481-492.

Gradey, J., 2003. Socio-économie des Services. La Decouverte, Paris.

Harrison, S., Herbohn, J., Niskanen, A., 2002. Non-industrial, smallholder, small-scale and family forestry: what's in a name? Small-scale Forest Economics Management and Policy 1 (1), 1-11.

Herbohn, J., 2006. Small-scale forestry: is it simply a smaller version of industrial (largescale) multiple use forestry? Small-scale forestry conference proceedings, 18-23 June. IUFRO, Galway, pp. 158-163.

Janzen, R., Sanberg, A., 1998. Good work, productivity and sustainability in Canadian forestry. Economic and Industrial Democracy 19, 119-135.

Karpinnen, H., 1998. Objectives of non-industrial private forest owners: differences and future trends in southern and northern Finland. Journal of Forest Economics 4, 147-174.

Kvarda, E., 2004. Non-agricultural forest owners in Austria: a new type of forest ownership. Forest Policy and Economics 6, 459-467.

Lilley, R., Feyer, A., Kirk, P., Gander, P., 2002. A survey of forest workers in New Zealand. Journal of Safety Research 33, 53-71.

Mäkinen, P., 1997. Success factors for forest machine entrepreneurs. Journal of Forest Engineering 8 (2), 27-35. 
Marey, M., Rodríguez, V., Crecente, R., 2007. Perfil del propietario forestal individual en Galicia: objetivos y prácticas de gestión en el noreste de la comunidad. Revista Galega de Economía 16 (1), 1-24.

Masden, L., 2003. New woodlands in Denmark: the role of private landowners. Urban Forestry and Urban Greening 1, 185-195.

Nordfjell, T., Kettunen, A., Vennesland, B., Suadicani, K., 2005. Family forestry: future changes and needs. Nordic Forest Research Co-operation Committee (SNS), Umea.

Normandin, D., 1996. La forêt paysanne en France: état des lieux et perspectives d'évolution. Études et recherches sur le développement 29, 195-211.

Novais, A., 2007. Lucro, Renda, Património e Risco nas Casas Agrícolas do Alentejo no Final do Século XIX: a Casa de Ficalho. Instituto Superior de Agronomia, Lisboa.

Novais, A., Canadas, M.J., 2007. Trabalho na Floresta: Fazer, Dar a Fazer ou não Fazer. III Congresso de Estudos Rurais, Faro.

Poschen, P., Lovgren, M., 2001. Globalization and Sustainability: The Forestry and Wood Industries on the Move. ILO, Geneva.

Radich, M., Baptista, F., 2005. Floresta e sociedade: um percurso (1875-2005). Silva Lusitana 13 (2), 143-157.
Rummukainen, A., Brogt, T., Kastenholz, E., 2006. Challenges for forestry contractors: various structures but mutual problems in Finland, Germany, Poland and Romania. In: Niskanen, A. (Ed.), Issues Affecting Enterprise Development in the Forest Sector in Europe. University of Joensu, Faculty of Forestry, Joensu, pp. 149-174.

Schlüter, A., 2007. Institutional change in the forestry sector: the explanatory potential of New Institutional Economics. Forest Policy and Economics 9 (8), 1090-1099.

Vokoun, M., Amacher, G., Wear, D., 2006. Scale of harvesting by non-industrial private landowners. Journal of Forest Economics 11, 223-244.

Wang, S., Kooten, C., 1999. Silvicultural contracting in British Columbia: a transaction cost economics analysis. Forest Science 45 (2), 272-279.

Westermayer, T., 2006. Out-sourcing of work in Germany's forestry: rural socia structure and identity in transformation. Albert-Ludwigs-Universität Freiburg im Breisgau, Freiburg.

Ziegenspeck, S., Härdter, U., Schraml, U., 2004. Lifestyles of private forest owners as an indication of social change. Forest Policy and Economics 6, 447-458. 